\title{
Influence of smoking on oral cells genotoxicity after at-home bleaching using $22 \%$ carbamide peroxide: a cohort study
}

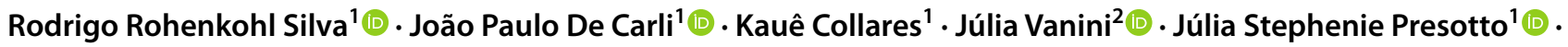 \\ José Eduardo Vargas ${ }^{3}$ - Alessandro D. Loguercio ${ }^{4}$ (i) $\cdot$ Paula Benetti $^{1}{ }^{\circledR}$
}

Received: 22 March 2021 / Accepted: 1 August 2021 / Published online: 17 August 2021

(c) The Author(s), under exclusive licence to Springer-Verlag GmbH Germany, part of Springer Nature 2021

\begin{abstract}
Objective This study evaluated the influence of smoking on the oral cells genotoxicity before and after at-home bleaching using $22 \%$ carbamide peroxide (CP).

Materials and methods This is a prospective observational analytics cohort study which evaluated nonsmokers (NS; $n=24)$ and smokers $(\mathrm{S} ; n=16)$ patients. At-home bleaching was performed using $22 \% \mathrm{CP}$ gel in individual trays for $1 \mathrm{~h}$ per day for 14 days in both groups. Scrapped cells from marginal gums were collected before the bleaching treatment (D0-baseline) and 1 day (D1), 15 days (D15), and 1 month (D30) after its finishing. Cells were stained with Giemsa 10\%, and the micronucleus (MN) and metanuclear alterations (MA) were counted by a trained operator in 1000 cells per patient. The collections and data analysis occurred blindly. Data was analyzed by Kruskal-Wallis, Dunn, and Mann-Whitney test $(\alpha=0.05)$.

Results MN frequency was not influenced by smoking or bleaching. An increase of MA was observed between D0 and D30 for both groups $(p<0.001)$; however, no statistical difference was found between NS and $\mathrm{S}(p>0.05)$ in the evaluation times. Conclusion Smoking associated with $22 \%$ carbamide peroxide gel for at-home bleaching does not show genotoxic potential analyzed by the MN counts. However, a significant increase of MA was found for smokers and nonsmokers.

Clinical relevance Despite of the increase in MA, smoking associated with $22 \%$ CP peroxide at-home bleaching showed no important genotoxic potential (MN) for oral cells. Therefore, at-home bleaching treatment is safe for nonsmokers and smokers even with a high carbamide peroxide concentration of $22 \%$.
\end{abstract}

Keywords Tooth bleaching $\cdot$ Carbamide peroxide $\cdot$ Genotoxicity $\cdot$ Smokers

\section{Introduction}

At-home bleaching is reported as an efficient, lasting, and conservative procedure to manage the esthetics problems related to darkened teeth $[1,2]$. The most frequently used agent is the carbamide peroxide $(\mathrm{CP})$ gel with concentrations varying from 10 to $22 \%$ used in individual trays for a

Paula Benetti

paulabenetti@upf.br

1 School of Dentistry, University of Passo Fundo, Campus I, BR 285, Passo Fundo, RS CEP 99001-970, Brazil

2 Department of Biological Sciences, Biological Sciences School, University of Passo Fundo, Passo Fundo, RS, Brazil

3 Cytogenetics Laboratory, Biological Sciences School, University of Passo Fundo, Passo Fundo, RS, Brazil

4 School of Dentistry, State University of Ponta Grossa, Ponta Grossa, PR, Brazil period that varies with the gel concentration and patients' characteristics [3, 4]. In contact with the enamel surface, the CP breaks down into urea and carbon dioxide and further on ammonia, water, and oxygen $[5,6]$. The generated reactive oxygen species and some free radicals break the double bonds of the organic and inorganic particles inside the dental structure [7].

Despite the desirable bleaching effect, a genotoxic potential of the reactive oxygen has been reported in the literature $[3,5,8,9]$. In contact with human cells, -OH radical can induce lipid peroxidation and DNA alteration followed by cell lysis and death [5]. Previous in vitro study [10] showed irreversible cytotoxic effects in cells exposed to $20 \% \mathrm{CP}$ for $1 \mathrm{~h}$. However, although no genotoxicity effect of lower concentration of $\mathrm{CP}$ was used [6,11-13], a closer view of clinical studies that evaluated higher concentrated bleaching materials for at-home technique showed controversial results in terms of micronucleus frequency [11, 13-15]. 
Genotoxicity is the ability of a substance to damage the human cells genetic content [16]. The micronucleus test consists in micronuclei (MN) formation count in cells and is frequently used to analyze the cytogenetic damage (such as the genotoxic effect of substances) on human target tissues such as oral mucosa, tongue, alveolar bone, gum, palate, and floor of the mouth $[11,12,16]$.

Smokers are commonly discouraged to perform bleaching treatments because of potentially lower efficiency of the bleaching treatment or teeth staining in these patients and the potential genotoxic effect (increase on MN counts) of the bleaching agent and cigarettes association [2, 12, 17-19]. In fact, cigarettes can present up to 3800 components and some of them with well-known genotoxic effect $[17,20]$. A previous study analyzed the potentialized cytotoxic effect of the association of $10 \% \mathrm{CP}$ bleaching and smoking [13]. This study showed an increase on the metanuclear alterations (MA), related to cells irritability, as a transitory effect (only during treatment) and no genotoxic effect (MN counts). With higher concentrations of $\mathrm{CP}$, this cytotoxic potential of smoking can be significantly increased, highlighting the importance of more studies on the area.

Given that both $\mathrm{CP}$ at higher concentrations and smoking have cytotoxic effects, the objective of this study is to analyze the influence of smoking on the oral cells genotoxicity after at-home bleaching using $22 \%$ carbamide peroxide (CP). The hypothesis 1 is that MA is not affected by the bleaching when compared smokers and nonsmokers. The hypothesis 2 is that $\mathrm{MN}$ is not affected by the bleaching when compared smokers and nonsmokers.

\section{Materials and methods}

\section{Ethical considerations.}

This study was approved by the University of Passo Fundo Ethics Committee (n. 3.095.118/2018) and registered at REBEC (Brazilian Register of Clinical trials, n. RBR$2 \times 2 \mathrm{czx}$, available at http://www.ensaiosclinicos.gov.br/rg/ RBR-2x2czx/). The report followed the recommendation of the STROBE (Strengthening the Reporting of Observational studies in Epidemiology) for this study.

\section{Study design}

This is a prospective observational cohort study. The project included the collection of marginal gingiva cells to access the frequency of micronuclei (DNA damage) and metanuclear alterations (binucleate cells, nuclear buds, nuclear alterations: karyorrhexis, picnose, karyolysis, and "brokenegg"). Thus, the main target of the present investigation is to evaluate the potential genotoxic effect of smoking and $22 \% \mathrm{CP}$.

\section{Sample selection}

\section{Inclusion criteria}

The study included nonsmokers and smokers of at least 5 cigarettes per day for more than 1 year which have not performed bleaching treatment for at least 6 years [21]. Volunteers aged between 18 and 54 years, presenting healthy anterior-superior teeth A2 (Vita Classical Shade Guide) or darker, were included [19].

\section{Exclusion criteria}

The study excluded the volunteers using orthodontic appliances (brackets), presenting caries, restorations, loss of pulp vitality, or any alterations (endodontic treatment, tetracycline stain, imperfect amelogenesis, fluorosis) that could result in color change of the upper and lower anterior teeth. Volunteers affected by periodontitis, bruxism, cervical lesions (erosion, abrasion, or attrition), or dentin sensitivity were also excluded [22]. Additionally, systemic conditions were also part of exclusion criteria: the presence of oral neoplasm or cancerous lesions, pregnancy or breastfeeding, decompensated diabetes, heart problems, and high blood pressure. Data from volunteers that were unable to attend any of assessments periods and collections with insufficient histopathological material for analysis were excluded.

\section{Sample size}

The sample size calculation was based on the frequency of MN per 1000 cells in adults. In the pilot study, it was observed that the normal frequency of MN was about $1 \pm 1.1$ $[15,19,21]$. Therefore, 32 patients (16 for each group) are required to have an $80 \%$ chance of detecting, as significant at the 5\% level, an increase in the primary outcome measure from 1 in the control group to 2 in the experimental group. A 75-100\% increase in sample size was considered for potential losses, refusals, and difficult of collections cells.

\section{Bleaching procedure}

For at-home bleaching, alginate (Avagel ${ }^{\mathrm{TM}}$; Dentsply, Milford, DE, USA) impressions were taken to obtain upper and lower arch stone models (Asfer ${ }^{\mathrm{TM}}$; São Caetano do Sul, SP, Brazil). The customized bleaching trays (without reservoirs $[23,24])$ were made pressing a soft 1 -mm-thick vinyl material (FGM ${ }^{\mathrm{TM}}$, Joinville, SC, Brazil) over the stone models using a vacuum plasticizer (Bio Art ${ }^{\mathrm{TM}}$; São Carlos, SP, Brazil). The excess of material was trimmed from the tray leaving a $1 \mathrm{~mm}$ marginal gum covered. In a clinical appointment, 
the trays fit to the arcs was checked, and the patients received two syringes of the bleaching agent gel (Whiteness Perfect $22 \%$, FGM Joinville, SC, Brazil) containing $22 \%$ carbamide peroxide, neutralized carbopol, potassium nitrate, sodium fluoride, humectant (glycol), and deionized water. Oral and written instructions on the bleaching protocol were given to the patients: application of a small amount (rice-size) for each tooth of the bleaching gel inside the tray, in the area corresponding on the buccal face of anterior teeth; wear during $1 \mathrm{~h}$ for 14 days.

\section{Training and examinations}

One examiner was trained by a clinical stomatologist to collect oral cells, and other one was trained by a cell biology specialist to perform cell analysis (MA and MN counting) in a pilot study. After training, a Kappa test was performed to assess the calibration between trainers and examiners $(k=0.90)$. Cells collections, histochemical laboratorial assessments, and statistical analysis occurred blindly. For cells collection, a special mask (N95, PFF2, 3 M, St. Paul, $\mathrm{MN}, \mathrm{USA}$ ) was used to prevent the detection of typical cigarette smell.

\section{Cell analysis}

Before the cells collection, all volunteers performed a mouthwash with water for 1 min to eliminate debris. Scrapped cells from the upper and lower marginal gums (area with the highest contact with the bleaching agent) were collected using a wooden spatula. Cells were collected before bleaching (D0-baseline) and 1 day (D1), 15 days (D15), and 30 days (D30) after the end of the treatment.

The collected material was transferred to a falcon tube, fixed using a 3:1 (volume) solution of methanol and acetic acid (Merck KGaA ${ }^{\mathrm{TM}}$, Darmstadt, Germany). The material was centrifuged at $1000 \mathrm{rpm}$ for $10 \mathrm{~min}$, and the supernatant was removed, remaining only the white pallet. The fixator was applied for the second time to rinse the cells, obtaining a colorless and clean (no debris) material. The material was dripped over histologic slides, left to dry at room temperature $\left(23{ }^{\circ} \mathrm{C}\right)$, and stained using $10 \%$ Giemsa (Renylab Química, Barbacena, MG, Brazil).

\section{Micronucleus and metanuclear alterations evaluation}

The criteria used for scoring micronucleus (MN) and metanuclear alterations (MA) were according to those described by Thomas et al. [25]. For each patient and each collection, 1000 cells were examined using an Olympus $\mathrm{BX} 50^{\mathrm{TM}}$ microscope (Corporation of the Americas, Center Walley, PA, USA) in a $100 \times$ magnification. The abnormalities were evaluated by assessing the staining intensity, texture, and focal plane of the nucleus. Normal cells were identified as follows: intact and relative homogeneous cytoplasm, little or no contact with adjacent cells, and an intact homogenous nucleus with a smooth and distinct nuclear perimeter $[25,26]$. The results are presented as the number of cells with MN and MA per 1000 cells.

The amount of observed MA, including binucleate cells, nuclear buds, nuclear alterations type 1 (karyorrhexis), 2 (picnose), 3 (karyolysis), and 4 ("broken-egg"), were recorded [14]. MN and MA were count following the criteria [25, 26]: Micronucleated cells were characterized by the presence of the main nucleus and a smaller one, called micronucleus, resulting from a chromosomal fragmentation by genotoxicity. The MN cells were characterized according to the following criteria: (a) regular contour, round or elliptical, and inside the cell cytoplasm; (b) similar color to the main nucleus; (c) less than onethird of the diameter of the nucleus; and (d) completely separated from the nucleus, allowing clear identification between the nucleus and MN limits. Karyorrhexis cells were characterized by more extensive chromatid aggregation indicating fragmentation and nuclear disintegration in the advanced stage of cell death by apoptosis. Pycnotic cells were characterized by a small nucleus with condensed chromatin and intense staining. Nuclear diameter is $1 / 3$ to $2 / 3$ smaller than that of the differentiated cells and is related to an advanced stage of cell death by necrosis. Karyolytic cells have a lightly stained chromatin, related to a more advanced stage of cell death process due to necrosis. "Broken egg" cells showed the main nucleus and the nearby accessory core connected by fine chromatin filaments. The accessory core has the same morphological and coloring characteristics as the main core, but a diameter less than $25 \%$ of the core. It is believed that this type of morphology originates from the presence of dicentric chromosomes with abnormal anaphasic behavior during segregation.

\section{Statistical analysis}

A descriptive analysis was performed. Differences on age between the S and NS groups were performed using chisquare test. Shapiro-Wilk test was used to analyze data distribution. Data failed normality and equal variances test; thus, MN and MA counts of the groups were compared using Kruskal-Wallis and Dunn post-hoc tests at the evaluation times. Finally, Mann-Whitney test was used to compare the MN and MA frequency between $\mathrm{S}$ and NS within the same evaluation time. Data analysis was performed using STATA $14^{\mathrm{TM}}$ (Statistics/Data Analysis, College Station, Texas, USA) software with an $\alpha=0.05$. 


\section{Results}

From the initially examined 96 volunteers (and $34 \mathrm{~S}$ and 62 NS), $6 \mathrm{~S}$ and $30 \mathrm{NS}$ were excluded from the study because they did not meet the eligibility criteria. Thus, the initial sample was composed of 60 participants $(28 \mathrm{~S}$ and 32 NS). During the follow-up times, 20 volunteers were lost (Fig. 1) due to the lack of time to attend the appointments, no show, or abandonment (no answer in contact attempts). In addition, data from $4 \mathrm{~S}$ and $1 \mathrm{NS}$ were excluded because collections had less than 1000 cells, which is insufficient for the analysis.

Demographic characteristics of the participants are shown in Table 1. No significant age differences were found between S and NS. Most of the volunteers were
Table 1 Volunteers' social-demographic characteristics

\begin{tabular}{lll}
\hline Characteristics & Groups & \\
\cline { 2 - 3 } & Smokers & Nonsmokers \\
\hline Female (\%) & $9(56 \%)$ & $16(67 \%)$ \\
Male (\%) & $7(44 \%)$ & $8(33 \%)$ \\
Age (years; mean \pm standard deviation) & $31.6( \pm 10.6)$ & $23.3( \pm 5.9)$ \\
$\begin{array}{l}\text { Cigarettes/day (mean } \pm \text { standard devia- } \\
\quad \text { tion) }\end{array}$ & $7.6( \pm 5.1)$ & - \\
$\begin{array}{l}\text { Smoking years (mean } \pm \text { standard devia- } \\
\text { tion) }\end{array}$ & $11.3( \pm 10.8)$ & - \\
\hline
\end{tabular}

Fig. 1 Flow diagram of the observational prospective study, including information of the excluded volunteers

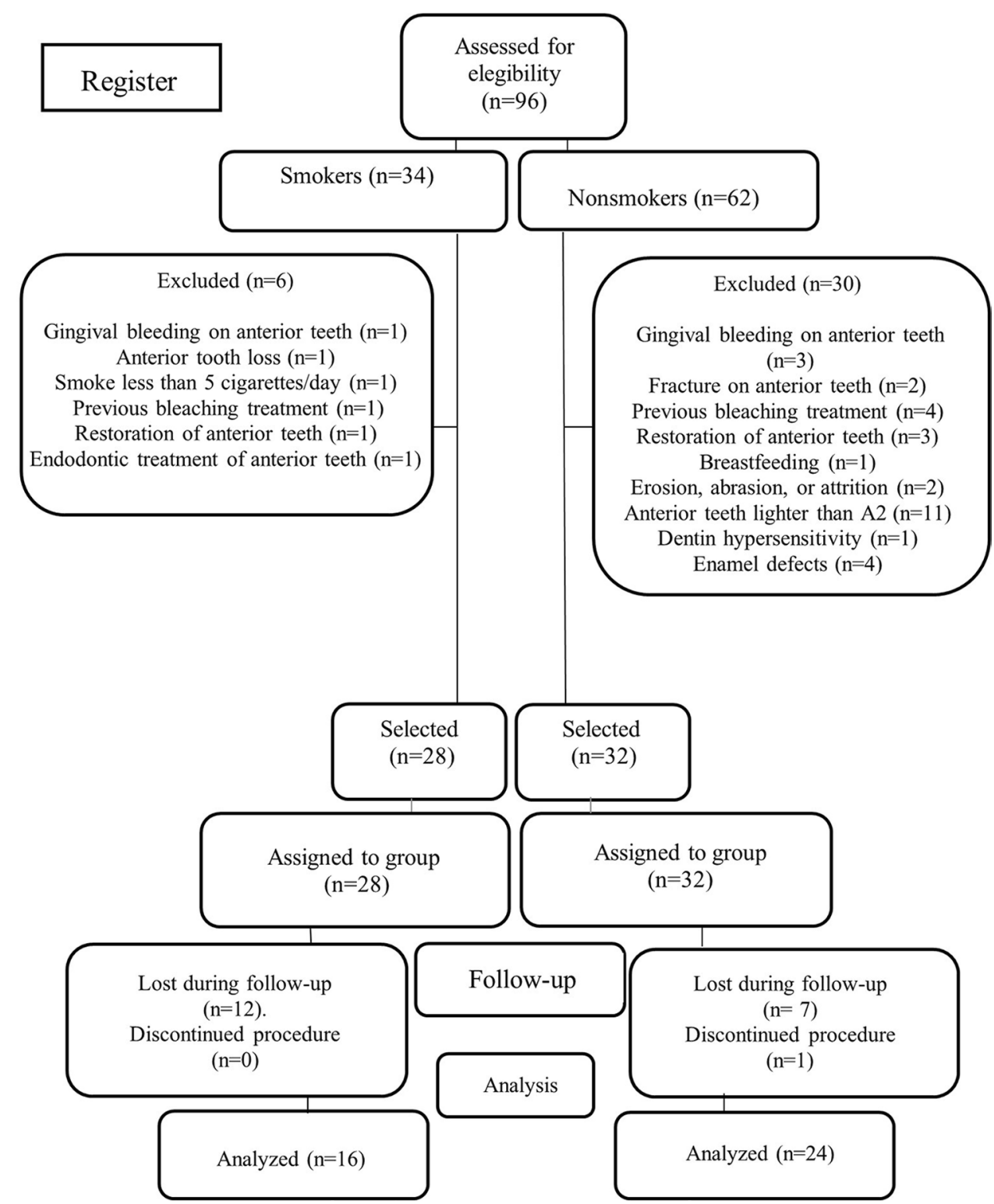


female. Smokers consumed 7.6 cigarettes per day on average.

The MA counts increased significantly at D30, compared to D0 ( $p<0.0001)$ for both groups (Fig. 2), while MN counts remained the same $(p>0.05)$.

Within the same evaluation times, no differences on MA and MN were found between S and NS ( $p>0.05)$ (Table 2).

\section{Discussion}

The present study showed no differences on MN and MA counts between smokers and nonsmokers neither before the bleaching treatment nor after its finishing, which lead us to not refuse the two null hypotheses. The potential genotoxic effect of the smoking and bleaching combination was probably neutralized by the eukaryotic cells [16]. As similar results were presented in previous studies $[11,27,28]$ which used carbamide peroxide, bleaching treatment is being demonstrated as safe for smokers as it is for nonsmokers.

The genotoxic potential of bleaching agents was mostly investigated by in vitro studies (cell cultures) [8] or animal models [29]. These studies use controlled peroxide concentrations (ranging from 0.03 to $30 \mathrm{mM}$ ) [30] resulting on a dose-dependent DNA damage increase [29, 30]. Due to the possibility of strict control of the concentration of bleaching agent in in vitro studies, most of the time, bleaching agents can be considered genotoxic in vitro but not in vivo [8]. In the clinical environment, the oral mucosa counts with many protective mechanisms, such as saliva, gingival crevicular fluid, tooth brushing, and cells exfoliation [7, 31]. In addition, oral mucosa cells present important antioxidant systems such as catalases, glutathione peroxidases (GSH-Px), and the superoxide dismutases (SODs), which are activated under oxidative stress and eliminate free radicals originated by the bleaching gel [7]. These mechanisms can contribute to reduce the genotoxicity of $\mathrm{CP}$ on smokers, highlighting
Fig. 2 Boxplots of metanuclear alterations (MA) counts in smokers and nonsmokers comparing the evaluated times. Different uppercase letters show statistical differences on MA counts between the evaluation times in the same group
Table 2 Comparison of metanuclear alterations (MA) and micronucleus (MN) median counts at determined evaluation times between smokers and nonsmokers $(*)$

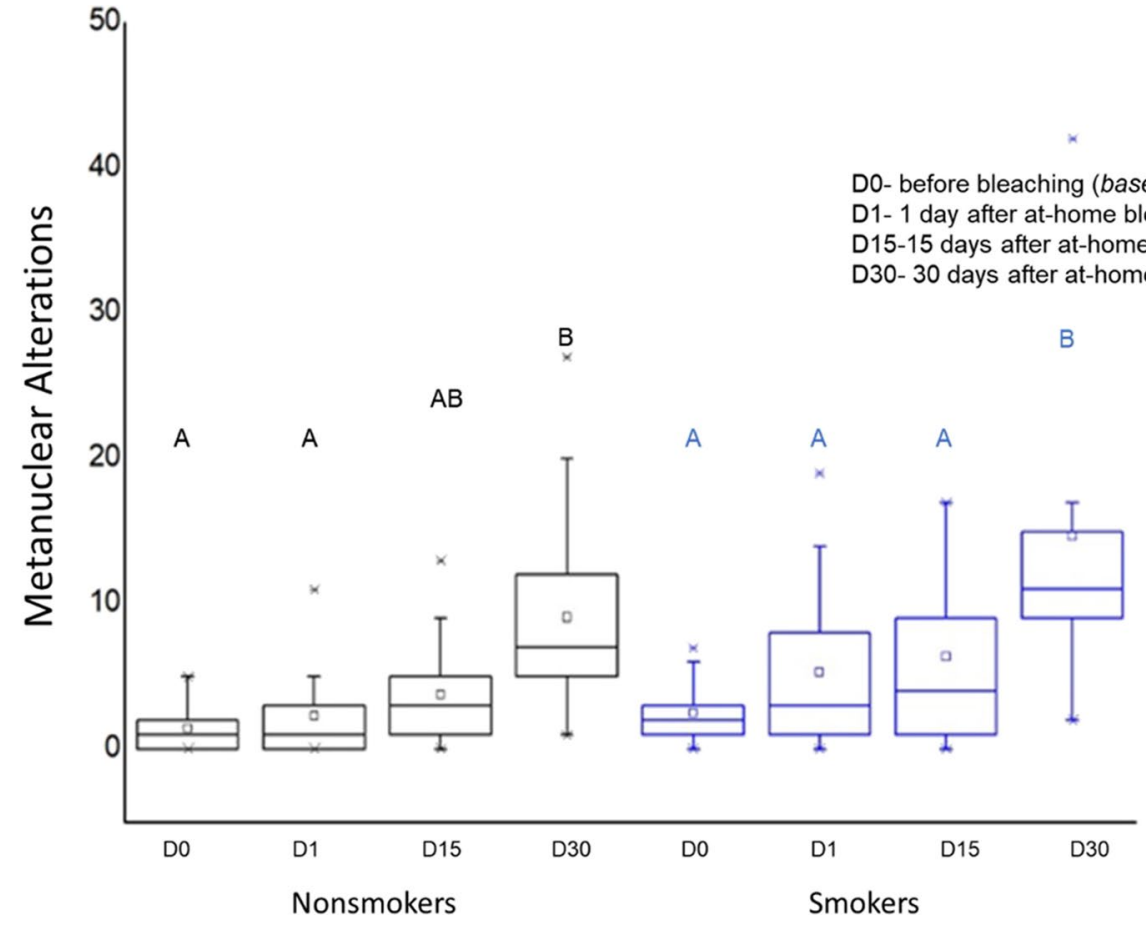

\begin{tabular}{|c|c|c|c|c|c|c|}
\hline & \multicolumn{2}{|c|}{ Metanuclear alterations (MA)* } & \multirow[t]{2}{*}{$p$-value } & \multicolumn{2}{|c|}{ Micronucleus (MN)* } & \multirow[t]{2}{*}{$p$-value } \\
\hline & Smokers & Nonsmokers & & Smokers & Nonsmokers & \\
\hline D1-D0 & $2.0(-1.5 ; 6.5)$ & $5.0(-1.0 ; 3.0)$ & 0.45 & $0(0 ; 0)$ & $0(0 ; 0)$ & 0.75 \\
\hline D15-D0 & $2.5(0 ; 8.0)$ & $1.0(-1.0 ; 5.0)$ & 0.41 & $0(0 ; 0)$ & $0(0 ; 0)$ & 0.23 \\
\hline D30-D0 & $8.5(3.0 ; 14.0)$ & $6.0(4.0 ; 10.0)$ & 0.32 & $0(0 ; 1)$ & $0(0 ; 1)$ & 0.82 \\
\hline D15-D1 & $-1.0(-3.5 ; 5.5)$ & $2.0(3.0 ; 10.0)$ & 0.25 & $0(0 ; 0)$ & $0(0 ; 0)$ & 0.63 \\
\hline D30-D1 & $6.0(1.0 ; 13.0)$ & $6.0(3.0 ; 10.0)$ & 0.25 & $0(0 ; 1)$ & $0(0 ; 1)$ & 0.90 \\
\hline
\end{tabular}

*Expressed by the median of counts (first and second quartiles). 
the importance of clinical studies, which considers the complexity of the oral environment.

Despite the most concerning side effect of bleaching substances and smoking is unquestionably its genotoxic potential, the presence of gingival irritation $[6,11]$, tooth sensitivity [24, 28, 32], and enamel hardness decrease is frequently reported in the literature [33, 34]. Soft tissue irritation can occur due to an inadvertent gel extrusion from the bleaching tray [11,35], which is made of a flexible silicon material and is extended in up to $1 \mathrm{~mm}$ over the gingival margin [23]. This unintentional contact of $\mathrm{CP}$ with the oral cells can result in injuries and ulcerations responsible for DNA interaction and oxidative damage changing the genetic content repair ability $[6,11,12,36]$.

The MN test was previously being used to evaluate the genotoxicity of CP and smoking [12, 15, 17, 18, 20], showing a potential genotoxic effect when these factors are evaluated separately. Both agents have the potential to cause genetic damage that could lead to cell cycle impairment, cell death, and malign neoplasms [16, 35]. It seems quite reasonable that the safety of the combination of both substances (CP and smoke) needed to be investigated. Previous study reported that in normal oral cell, up to $2.0 \mathrm{MN} / 1000$ cells (1.7\%) can normally be present [37]. In the present study, both evaluation groups showed MN counts lower than this normal value, suggesting no genotoxicity of bleaching with $22 \% \mathrm{CP}$ and smoking on the tested population and agreeing with data from the literature which report average $\mathrm{MN}$ counts/1000 cells between 0.4 and 2 [11, 15].

Comparing MN and MA frequency in smokers and nonsmokers, the present study showed that smoking, associated or not to $22 \% \mathrm{CP}$, did not show genotoxic effect on oral mucosa cells, differently from previously published report [12]. Distinct results obtained by the studies could be attributed to variations in the daily amount of cigarettes consumed, which is associated to $\mathrm{MN}$ increase in exfoliated mucosa oral cells comparing smokers to nonsmokers [37]. The volunteers of the present study used to smoke approximately a half of the cigarettes (7.6) of the previous study volunteers (13.2) [12], which could have reduced the genotoxic effect of tobacco and other substances since this is a dose-dependent response [29, 30].

The present study demonstrated no genotoxic effect (MN counts) of smoking and bleaching, but a significant increase of metanuclear alterations (MA) was observed from the treatment start to 30 days after bleaching. MA counts represents less serious changes in oral cells (death by necrosis or apoptosis) than MN (loss of genetic material and atypical mitosis) for cancerization but can represent an irritation of oral cells [15]. Previous in vitro studies have investigated cells proliferative response (normal epithelium response) to the oxidative stress potentially caused by the whitening products. Such approaches demonstrated that a similar cell irritation response occurs after carbamide and hydrogen peroxides gel exposure, characterized by morphological alterations of the oral mucosa tissues, increased cells proliferation and apoptotic cells (cells death) in multiple layers of the epithelium (including basal and suprabasal layers) after exposure to whitening products $[35,38]$. In addition, no differences on cells irritation were found between smokers and nonsmokers [38], agreeing with the present study findings.

Most of the studies on CP genotoxicity observed inexpressive $\mathrm{MN}$ counts during and after bleaching (no genotoxic effect) $[6,11,12,27]$. A previous study of our group [15] evaluated MA counts during and after at-home bleaching using $22 \% \mathrm{CP}$. The frequency MA significantly increased during the treatment and reduced to baseline values 30 days after the bleaching conclusion. In the present study, however, MA frequency showed no reduction and continued to increase in $\mathrm{S}$ group by 30 days after finishing the bleaching treatment $(p<0.0001)$, highlighting the importance of extended periods of evaluation. Based on these data and the incipient literature reporting the genotoxic effect of the combination of $22 \% \mathrm{CP}$ and smoking, further studies should be conducted with longer follow-up times to reach the effect of cells exfoliating and turnover times [39]. While morphologic alterations, cells proliferation, and induction to apoptosis were seen in the oral mucosa cells exposed to whitening products, it is important to notice that previous studies have demonstrated that the tissues maintained their viability [15, $35,38]$. Oral mucosa cells continually proliferate and induce cells death to maintain their barrier function in response to injury $[35,38]$. Therefore, it may be speculated that the metanuclear alterations and micronucleus incidence would fall to reference level after stop of the at-home bleaching. Our first study design included larger follow-up times $(2,3$, and 6 months after bleaching); however data collection was interrupted due to the COVID-19 pandemic, and only data from evaluation times up to 30 days after bleaching were included in the analysis.

\section{Conclusion}

The smoking habit associated with $22 \%$ carbamide peroxide gel for at-home bleaching does not show genotoxic potential when MN was evaluated. However, a significant increase proportional to evaluating times of MA was found for smokers and nonsmokers subjects.

Acknowledgements The authors thank the Post Graduate Program in Dentistry, Faculty of Dentistry, University of Passo Fundo, and FGM (Joinville, SC, Brazil) for providing the materials used in the present study.

Author contribution Conceptualization: Paula Benetti, João Paulo De Carli, Kauê Collares. 
Study design/methodology: Paula Benetti, João Paulo De Carli, Kauê Collares.

Data collection: Rodrigo Rohenkohl Silva, Júlia Vanini, Júlia Stephenie Presotto, José Eduardo Vargas.

Formal analysis and investigation: Kauê Collares; Rodrigo Rohenkohl Silva; Alessandro Dourado Loguercio.

Writing — original draft preparation: Rodrigo Rohenkohl Silva, João Paulo De Carli.

Writing—review and editing: Paula Benetti, João Paulo De Carli, Kauê Collares, José Eduardo Vargas; Alessandro Dourado Loguercio.

All the mentioned authors had an important intellectual to the conception and design of the work and to the execution of the protocols of the research, data acquisition and analysis, interpretation of the results, and writing and critically revising the manuscript. The authors agreed in all aspects of the work, ensuring that questions related to the work were appropriately investigated and resolved. In addition, the authors approve the presented version of the manuscript.

Funding This study was performed by Rodrigo Rohenkohl Silva as partial fulfillment of his Master degree at the University of Passo Fundo (UPF), Passo Fundo, RS, Brazil. This project was partially supported by the Post Graduate Program in Dentistry, Faculty of Dentistry, UPF (scholarship).

\section{Declarations}

Ethical approval This study was approved by the University of Passo Fundo Ethics Committee (n. 3.095.118/2018) and registered at REBEC (Brazilian Register of Clinical trials, n. RBR- $2 \times 2 \mathrm{czx}$, available at http://www.ensaiosclinicos.gov.br/rg/RBR-2x2czx/).

Informed consent All the volunteers who met inclusion and exclusion criteria signed an informed consent form.

Conflict of interest The authors declare no competing interests.

\section{References}

1. Meireles SS, Santos IS, Bona AD, Demarco FF (2010) A doubleblind randomized clinical trial of two carbamide peroxide tooth bleaching agents: 2-year follow-up. J Dent 38:956-963. https:// doi.org/10.1016/j.jdent.2010.08.003

2. Haywood VB and Sword RJ (2020) Tray bleaching status and insights. Journal of esthetic and restorative dentistry : official publication of the American Academy of Esthetic Dentistry [et al]. doi: https://doi.org/10.1111/jerd.12688

3. Dahl JE, Pallesen U (2003) Tooth bleaching-a critical review of the biological aspects. Crit Rev Oral Biol Med 14:292-304. https://doi.org/10.1177/154411130301400406

4. de Geus JL, Wambier LM, Boing TF, Loguercio AD, Reis A (2018) At-home bleaching with $10 \%$ vs more concentrated carbamide peroxide gels: a systematic review and meta-analysis. Oper Dent 43:E210-E222. https://doi.org/10.2341/17-222-L

5. Goldberg M, Grootveld M, Lynch E (2010) Undesirable and adverse effects of tooth-whitening products: a review. Clin Oral Invest 14:1-10. https://doi.org/10.1007/s00784-009-0302-4

6. Almeida AF, Torre Edo N, Selayaran Mdos S, Leite FR, Demarco FF, Loguercio AD and Etges A (2015) Genotoxic potential of 10\% and $16 \%$ carbamide peroxide in dental bleaching. Braz Oral Res 29. https://doi.org/10.1590/1807-3107BOR-2015.vol29.0021

7. Jha N, Ryu JJ, Choi EH, Kaushik NK (2017) Generation and role of reactive oxygen and nitrogen species induced by plasma, lasers, chemical agents, and other systems in dentistry. Oxid Med Cell Longev 2017:7542540. https://doi.org/10.1155/2017/ 7542540

8. Munro IC, Williams GM, Heymann HO, Kroes R (2006) Use of hydrogen peroxide-based tooth whitening products and its relationship to oral cancer. J Esthet Restor Dent 18:119-125. https:// doi.org/10.1111/j.1708-8240.2006.00006.x

9. Naik S, Tredwin CJ, Scully C (2006) Hydrogen peroxide toothwhitening (bleaching): review of safety in relation to possible carcinogenesis. Oral Oncol 42:668-674. https://doi.org/10.1016/j. oraloncology.2005.10.020

10. Fernandes AMM, Vilela PGF, Valera MC, Bolay C, Hiller KA, Schweikl H, Schmalz G (2018) Effect of bleaching agent extracts on murine macrophages. Clin Oral Invest 22:1771-1781. https:// doi.org/10.1007/s00784-017-2273-1

11. Rezende M, De Geus JL, Loguercio AD, Reis A, Kossatz D (2016) Clinical evaluation of genotoxicity of in-office bleaching. Oper Dent 41:578-586. https://doi.org/10.2341/15-207-C

12. de Geus JL, Rezende M, Margraf LS, Bortoluzzi MC, Fernandez E, Loguercio AD, Reis A, Kossatz S (2015) Evaluation of genotoxicity and efficacy of at-home bleaching in smokers: a singleblind controlled clinical trial. Oper Dent 40:E47-55. https://doi. org/10.2341/14-121-C

13. de Geus JL, Bortoluzzi MC, Reis A, Loguercio AD (2019) Do dental bleaching agents induce genetic damage on oral mucosa cells? Clin Oral Invest 23:2511-2513. https://doi.org/10.1007/ s00784-019-02873-5

14. Del Real Garcia JF, Saldana-Velasco FR, Sanchez-de la Rosa SV, Ortiz-Garcia YM, Morales-Velazquez G, Gomez-Meda BC, Zuniga-Gonzalez GM, Sanchez-Parada MG, Zamora-Perez AL (2019) In vivo evaluation of the genotoxicity and oxidative damage in individuals exposed to $10 \%$ hydrogen peroxide whitening strips. Clin Oral Invest 23:3033-3046. https://doi.org/10.1007/ s00784-018-2716-3

15. Bonacina LVVC, Vanini J, Zandoná J, Silva RR, Busin CS, Benetti P, Carli JP (2020) Genotoxicity of $22 \%$ carbamide peroxide bleaching agent on oral cells using the micronucleus technique. J Clin Diagn Res 14:3. https://doi.org/10.7860/JCDR/2020/43341. 13569

16. Ribeiro DA, Yujra VQ, CFG DEM, Handan BA, M DEBV, Yamauchi LY, Castelo PM and Aguiar O, Jr. (2017) Genotoxicity induced by dental materials: a comprehensive review. Anticancer Res 37:4017-4024. https://doi.org/10.21873/anticanres.11786

17. Bansal H, Sandhu VS, Bhandari R, Sharma D (2012) Evaluation of micronuclei in tobacco users: a study in Punjabi population. Contemp Clin Dent 3:184-187. https://doi.org/10.4103/0976237X.96825

18. Naderi NJ, Farhadi S, Sarshar S (2012) Micronucleus assay of buccal mucosa cells in smokers with the history of smoking less and more than 10 years. Indian J Pathol Microbiol 55:433-438. https://doi.org/10.4103/0377-4929.107774

19. de Geus JL, Bersezio C, Urrutia J, Yamada T, Fernandez E, Loguercio AD, Reis A, Kossatz S (2015) Effectiveness of and tooth sensitivity with at-home bleaching in smokers: a multicenter clinical trial. J Am Dent Assoc 146:233-240. https://doi.org/10. 1016/j.adaj.2014.12.014

20. Suhas S, Ganapathy KS, Gayatri Devi M, Ramesh C (2004) Application of the micronucleus test to exfoliated epithelial cells from the oral cavity of beedi smokers, a high-risk group for oral cancer. Mutat Res 561:15-21. https://doi.org/10.1016/j.mrgentox.2004. 03.001

21. Knutsson BMS, Wahlström MJ, Järvholm B, Sayeed-Noor AS (2017) The association between tobacco smoking and surgical intervention for lumbar spinal stenosis: cohort study of 331,941 workers. Spine J 18:5. https://doi.org/10.1016/j.spinee.2017.11. 018 
22. Titenko-Holland N, Windham G, Kolachana P, Reinisch F, Parvatham S, Osorio AM, Smith MT (1997) Genotoxicity of malathion in human lymphocytes assessed using the micronucleus assay in vitro and in vivo: a study of malathion-exposed workers. Mutat Res 388:85-95. https://doi.org/10.1016/s1383-5718(96) 00140-4

23. Kirsten GA, Freire A, de Lima AA, Ignacio SA, Souza EM (2009) Effect of reservoirs on gingival inflammation after home dental bleaching. Quintessence Int 40:195-202

24. Maran BM, Vochikovski L, de Andrade Hortkoff DR, Stanislawczuk R, Loguercio AD, Reis A (2018) Tooth sensitivity with a desensitizing-containing at-home bleaching gel-a randomized triple-blind clinical trial. J Dent 72:64-70. https://doi.org/10. 1016/j.jdent.2018.03.006

25. Thomas P, Holland N, Bolognesi C, Kirsch-Volders M, Bonassi S, Zeiger E, Knasmueller S, Fenech M (2009) Buccal micronucleus cytome assay. Nat Protoc 4:825-837. https://doi.org/10.1038/ nprot.2009.53

26. Bolognesi C, Knasmueller S, Nersesyan A, Thomas P, Fenech M (2013) The HUMNxl scoring criteria for different cell types and nuclear anomalies in the buccal micronucleus cytome assay - an update and expanded photogallery. Mutat Res 753:100-113. https://doi.org/10.1016/j.mrrev.2013.07.002

27. Monteiro MJF, Lindoso JBC, de Oliveira Conde NC, da Silva LM, Loguercio AD, Pereira JV (2019) Evaluation of the genotoxic potential of different delivery methods of at-home bleaching gels: a single-blind, randomized clinical trial. Clin Oral Invest 23:2199-2206. https://doi.org/10.1007/s00784-018-2659-8

28. Bernardon JK, Vieira Martins M, BrancoRauber G, Monteiro Junior S, Baratieri LN (2016) Clinical evaluation of different desensitizing agents in home-bleaching gels. J Prosthet Dent 115:692-696. https://doi.org/10.1016/j.prosdent.2015.10.020

29. de Castro AR, Gomez RS, Dutra RA, Vasconcellos WA, Gomez RS, Gomez MV (2002) Effects of a $10 \%$ carbamide peroxide bleaching agent on rat oral epithelium proliferation. Braz Dent $\mathbf{J}$ 13:162-165. https://doi.org/10.1590/s0103-64402002000300003

30. Pligina KL, Rodina IA, Shevchenko TV, Bekchanova ES, Tikhonov VP, Sirota NP (2012) DNA-damaging effects of dental bleaching agents. Bull Exp Biol Med 153:57-60. https://doi.org/ 10.1007/s10517-012-1642-7

31. Colares VLP, Lima SNL, Sousa NCF, Araujo MC, Pereira DMS, Mendes SJF, Teixeira SA, Monteiro CA, Bandeca MC, Siqueira WL, Moffa EB, Muscara MN, Fernandes ES (2019) Hydrogen peroxide-based products alter inflammatory and tissue damagerelated proteins in the gingival crevicular fluid of healthy volunteers: a randomized trial. Sci Rep 9:3457. https://doi.org/10.1038/ s41598-019-40006-w

32. Kossatz S, Martins G, Loguercio AD, Reis A (2012) Tooth sensitivity and bleaching effectiveness associated with use of a calcium-containing in-office bleaching gel. J Am Dent Assoc 143:e81-e87. https://doi.org/10.14219/jada.archive.2012.0075

33. Akarslan ZZ, Sadik B, Erten H, Karabulut E (2009) Dental esthetic satisfaction, received and desired dental treatments for improvement of esthetics. Indian J Dent Res 20:195-200. https:// doi.org/10.4103/0970-9290.52902

34. Grazioli G, Valente LL, Isolan CP, Pinheiro HA, Duarte CG, Munchow EA (2018) Bleaching and enamel surface interactions resulting from the use of highly-concentrated bleaching gels. Arch Oral Biol 87:157-162. https://doi.org/10.1016/j.archoralbio.2017. 12.026

35. Lucier RN, Etienne O, Ferreira S, Garlick JA, Kugel G, Egles C (2013) Soft-tissue alterations following exposure to tooth-whitening agents. J Periodontol 84:513-519. https://doi.org/10.1902/ jop.2012.100383

36. Kawamoto K, Tsujimoto Y (2004) Effects of the hydroxyl radical and hydrogen peroxide on tooth bleaching. J Endod 30:45-50. https://doi.org/10.1097/00004770-200401000-00010

37. Bonassi S, Coskun E, Ceppi M, Lando C, Bolognesi C, Burgaz S, Holland N, Kirsh-Volders M, Knasmueller S, Zeiger E, Carnesoltas D, Cavallo D, da Silva J, de Andrade VM, Demircigil GC, Dominguez Odio A, Donmez-Altuntas H, Gattas G, Giri A, Giri S, Gomez-Meda B, Gomez-Arroyo S, Hadjidekova V, Haveric A, Kamboj M, Kurteshi K, Martino-Roth MG, Montero Montoya R, Nersesyan A, Pastor-Benito S, FaveroSalvadori DM, Shaposhnikova A, Stopper H, Thomas P, Torres-Bugarin O, Yadav AS, Zuniga Gonzalez G, Fenech M (2011) The HUman MicroNucleus project on eXfoLiated buccal cells (HUMN(XL)): the role of lifestyle, host factors, occupational exposures, health status, and assay protocol. Mutat Res 728:88-97. https://doi.org/10.1016/j.mrrev. 2011.06.005

38. da Costa Filho LC, da Costa CC, Soria ML, Taga R (2002) Effect of home bleaching and smoking on marginal gingival epithelium proliferation: a histologic study in women. J Oral Pathol Med 31:473-480. https://doi.org/10.1034/j.1600-0714.2002.00110.x

39. Tadin A, Gavic L, Zeravica A, Ugrin K, Galic N, Zeljezic D (2018) Assessment of cytotoxic and genotoxic effects of conventional and whitening kinds of toothpaste on oral mucosa cells. Acta Odontol Scand 76:64-70. https://doi.org/10.1080/00016357. 2017.1384567

Publisher's note Springer Nature remains neutral with regard to jurisdictional claims in published maps and institutional affiliations. 